\title{
DATING WHITMAN'S LANGUAGE STUDIES
}

\author{
JAMES PerRIN WARREN
}

IN Walt Whitman: A Life, Justin Kaplan implies that Whitman began studying historical linguistics with William Swinton in late 1857 or early $1858 .^{1}$ Kaplan's implied dating appears to be based on the scholarship of two Whitman authorities. First, in his edition of Whitman's two linguistic notebooks, Words and The Primer of Words, William White says that "sometime after 1856 Whitman cut out most of the pages of a book and kept in the stubs so that he could tip in sheets of paper, left over green wrappers from the first (1855) Leaves of Grass, City of Williamsburgh unused tax forms, endpapers from the second (1856) Leaves, and other sheets and scraps of various colors."2 Second, Fredson Bowers conjectures that Whitman began to use the Williamsburgh tax forms in February 1857, and the earliest dated use of the forms is 17 June 1857, when Whitman used the back of a form to make out a receipt to James Parton. ${ }^{3}$ So the bibliographical evidence that Whitman's language studies took place after 1856-and perhaps as late as 1857 or $1858-$ is indeed strong. I would like to present new evidence, however, which indicates an earlier date for Whitman's language studies.

Let us first return to White's description of the Words notebook. White bases the post-1856 date, in part, on the yellow endpapers, which he identifies as coming from the second edition of Leaves. Now, it is true that the 1856 edition of Leaves does have yellow endpapers, but the second issue of the 1855 edition also has yellow endpapers. Furthermore, in the catalogue for the Detroit exhibition of the Charles E. Feinberg Collection, Frances J. Brewer identifies the yellow endpapers as "left from the second issue of Leaves of Grass."4 I have compared the 1856 endpapers with the yellow endpapers of an 1855 issue, and the two are practically indistinguishable. But given Brewer's description, we may at least doubt White's dating of the Words notebook.

White's description of Word's includes "sheets and scraps of various colors," and the largest number of those sheets is "salmon-colored." The salmon sheets are important because they contain Whitman's linguistic notes on Christian C. J. Bunsen's Outlines of the Philosophy of Universal History, Applied to Language and Religion. ${ }^{6}$ Floyd Stovall notes that another group of Whitman's notes on Bunsen's Outlines, now in the Trent Collection, are "in black ink on pink paper like one type of the wrappers used on the 1855 Leaves of Grass, and were therefore probably made after June 1855." 7 I have not examined the "pink paper" notes in the Trent Collection, and it would be physically difficult, in any case, to compare the Words salmon sheets with the Trent pink ones. But I have examined both the sheets used in Words 
and the Primer and the "pink" wrappers of the 1855 Leaves of Grass, and the results of the comparison are suggestive.

The Primer notes appear on several types of paper, and three types unquestionably come from 1855 wrappers: the backs of green, light pink, and tannish yellow sheets often bear marks of the "Leaves of Grass." inscription. In addition, some thirteen sheets are on the Williamsburgh tax forms. ${ }^{8}$ Most importantly, there are sheets of two other shades of "pink" or "salmon." The first of these is lighter than the shade in the 1855 wrapper preserved in the Feinberg Collection at the Library of Congress. The second is darker than the 1855 wrapper, and ten sheets of this darker shade match the Words salmon sheets exactly. ${ }^{9}$

C. Carroll Hollis has argued that the Primer notes date from the early and middle months of 1856, for on the back of a green Primer sheet Whitman drew two elaborate sketches for the spine of the 1856 edition of Leaves. ${ }^{10}$ Given the connections between the salmon sheets used in Words and the Primer, then, we might be tempted to conclude that Whitman began the Words notebook before the publication of the 1856 Leaves. That conjecture becomes a near certainty when we consider the following words from a Primer salmon sheet:

America owes immeasurable respect and love to the past, and to many ancestries, for many inheritances - but of all that America has rec'd from the past, from the mothers and fathers of laws, arts, letters, \&c. by far the greatest inheritance is the English Languageso long in growing - so fitted [ $D B N$ III, 753]

The Primer passage is a rough draft of Whitman's opening paragraph to "America's Mightiest Inheritance," an article that appeared in the 12 April 1856 issue of Fowler and Wells's magazine Life Illustrated, a "Journal of Entertainment, Improvement, and Progress." Here is Whitman's printed text:

The English Language. - What would you name as the best inheritance America receives from all the processes and combinations, time out of mind, of the art of man? One bequest there is that subordinates any perfection of politics, erudition, science, metaphysics, inventions, poems, the judiciary, printing, steam-power, mails, architecture, or what not. This is the English language-so long in growing, so sturdy and fluent, so appropriate to our America and the genius of its inhabitants. ${ }^{11}$

The core of the parallel ("the English language-so long in growing") is obvious. The notebook version of the passage shows Whitman musing aloud, while the printed version shows his further reflection and careful attention to rhetoric, style, and audience.

Because the salmon sheets in the Primer definitely match those in Words, and because the Primer salmon sheets certainly date from before 12 April 1856 , we can safely conjecture that the salmon sheets from Words could date from about the same time. The evidence is not totally conclusive, but it 
strongly suggests that Whitman was actively studying historical linguistics before the second edition of Leaves of Grass appeared in September 1856.

The 1856 date runs counter to Bowers's conjectured dating of the blue tax-form pages. Whitman used the tax forms and the "pink" wrappers as late as $1858-1859$, when he was preparing the final drafts of the 1860 poems. ${ }^{12}$ We do not know when Whitman gathered and arranged the sheets in the form of the Words notebook, and the Primer notes are unbound. So Bowers's dating of the tax forms does open my conjectured dating to doubt, even though the double connection of the Primer salmon sheets to both "America's Mightiest Inheritance" and Words would lead us to think otherwise.

Two pieces of evidence relating to the tax forms support the earlier dating of Whitman's studies. First, on the verso of a small piece of tax form in Words, Whitman wrote the following humorous note:

Tracing words to origins

To get in the habit of tracing words to their root-meanings.
as for instance in the phrase "Rev. Mr. Conway"
trace "Reverend"
" "Mr."

-how inapplicable and superfluous so many words are! [DBN III, 725]

It is certain that Whitman tried to cultivate the habit of tracking down the origins of the words he used. On the back of the only extant manuscript page of the 1855 Leaves of Grass, Whitman made a list of ninety-one common words. Next to all but six of the words he placed a single letter (either $f, g, l$, or $c$ ) corresponding to the etymological source of the word (French, Gothic, Latin, and Celtic). Because many of the words were used in the "BroadAxe Poem," which appeared in the 1856 Leaves, we can be reasonably certain that Whitman was at least attempting to form the habit of tracing the origins of common words before September 1856. ${ }^{13}$ The tax-form page from Words seems to be an early self-admonition; the word-list shows that Whitman took his own advice seriously. From the circumstantial evidence, then, we could conclude that Whitman was using the tax forms before the 1856 edition of Leaves appeared.

The second piece of evidence does not directly concern Whitman's studies in historical linguistics, but it does support a pre-1856 date for the tax forms. On the verso of the top half of a tax form, Whitman wrote 128 words concerning "Ideas of Punishment-Reward, Woman, Liberty."14 Over one phrase ("the relation of master and slave is to go the: same road out of These States, that the relation of kings, lords, and commons, has gone") Whitman wrote in brackets, "this was written in 1855." Whitman had already written the bracketed note when he gave the tax-form sheet to Horace Traubel in 1888 , and he could easily have made a mistake about the date. But the 
note is none the less intriguing, for it does suggest an even earlier date for Whitman's use of the tax forms.

The purely bibliographical evidence indicates that Whitman was engaged in studying historical linguistics before the 1856 Leaves of Grass was published. The evidence is not conclusive, but it does suggest that Whitman had begun his two notebooks, Words and the Primer, before "America's Mightiest Inheritance" appeared in April 1856. In order to strengthen my conjectured dating, I want to consider briefly Whitman's purpose in keeping the language notebooks.

Michael Dressman has shown that Whitman's notebooks are part of his plan for a "true Dictionary" that would be more than "merely a collection of words." 15 The germ of that plan is already contained in the 1855 edition of Leaves of Grass. In what would later become Section 23 of "Song of Myself," Whitman raises a cheer for science, and two of the scientists he mentions are connected to his own plans for a new dictionary:

Hurrah for positive science! Long live exact demonstration!

Fetch stonecrop and mix it with cedar and branches of lilac;

This is the lexicographer or chemist .... this made a grammar of the old cartouches, These mariners put the ship through dangerous unknown seas,

This is the geologist, and this works with the scalpel, and this is a mathematician. ${ }^{16}$

In the center of the stanza Whitman sounds his praise for the lexicographer and the comparative philologist. The phrase "this made a grammar of the old cartouches" refers to the work of François Champollion, who deciphered the Egyptian hieroglyphics by using the ring-enclosed names of Ptolemy and Cleopatra on the Rosetta Stone. The ring, forming the so-called "cartouche," was supposed to protect the royal personage from harmful magic, and an illustration of a cartouche was printed in the 8 December 1855 issue of Life Illustrated to accompany Whitman's article on "The Egyptian Museum" of Dr. Henry Abbott. ${ }^{17}$

Whitman's dictionary project resurfaces in two important places. First, in "America's Mightiest Inheritance":

A Perfect English Dictionary has yet to be Written. - Largeness of mind is more indispensable in Lexicography than in any other science. To make a noble dictionary of the English speech is a work yet to be performed. Dr. Johnson did well; Sheridan, Walker, Perry, Ash, Bailey, Kenrick, Smart, and the rest, all assisted; Webster and Worcester have done well; and yet the dictionary, rising stately and complete, out of a full appreciation of the philosophy of language, and the unspeakable grandeur of the English dialect, has still to be made-and to be made by some coming American worthy the sublime work. ${ }^{18}$

Second, in the Preface to the 1856 Leaves: 
There is not a single History of the World. There is not one of America, or of the organic compacts of These States, or of Washington, or of Jefferson, nor of Language, nor any Dictionary of the English Language. ${ }^{19}$

The two passages show that Whitman associated his dictionary project with both the role of America in world history and the role of American English in linguistic history. Moreover, by emphasizing America's lack of a "Perfect English Dictionary," Whitman rhetorically takes the first step toward becoming the "coming American worthy the sublime work." And by placing his numerous predecessors within an historical process of perpetual progress, Whitman clears the lexicographical path before him.

Taken together, Whitman's two language notebooks, the two Life Illustrated essays, and the 1856 Preface indicate that in 1855-1856 Whitman's strong belief in "positive science" was finding a focus in a detailed study of language. Both the Primer and Words are notes toward a set of lessons which would open up new linguistic vistas for the American people. The purpose of Whitman's project can be seen clearly in the titles he proposed for his book. In Words he wrote two pages of titles, one on a tax form and one on a salmon sheet. The names include "Hints and Lessons," "Primary Lessons," "American Lessons," and "Walt Whitman's Primer" (DBN III, 712, 724). In the Primer notes we find "A Suggestive Primer" and "The Primer of Words," as well as the long subtitle "For American Young, Men, and Women, For Literats, Orators, Teachers, Musicians, Judges, Presidents, \&c." (DBN III, 728). The connection between the two notebooks is clearly drawn in the titles, and the subtitle of the Primer links it directly to the didactic, democratic purpose of the "Appendant for Working-People, Young Men and Women, and for Boys and Girls" in "America's Mightiest Inheritance."20

Whitman did not write his praises of language and then turn to the study of language, nor did he study language and then write poems to embody linguistics concepts. Both processes were taking place at about the same time, and each one affected the other in a variety of ways. I do not have space here to enter into the relationship of Whitman's poetry to his language studies, but I will close by suggesting that the "language experiment" of Leaves of Grass is the product of those mingled processes.

\section{Université de Genève}

\section{NOTES}

1 Justin Kaplan, Walt Whitman: A Life (New York: Simon and Schuster, 1980), pp. 223232.

2 Walt Whitman, Daybooks and Notebooks, ed. William White (New York: New York University Press, 1977), III, 664, n. 3436. Words appears in DBN III, 664-727; the Primer in 
$D B N$ III, 728-757; other notebooks and fragments in DBN III, 759-825. All quotations of Whitman's notes are taken from this edition, which is refered to as "DBN III" in the body of the essay.

3 Fredson Bowers, Whitman's Manuscripts: Leaves of Grass (1860) (Chicago: Univ. of Chicago Press, 1955), pp. xli-xliii, xlix, n. 23.

4 Frances J. Brewer, Walt Whitman; a Selection of the Manuscripts, Books and Association Items Gathered by Charles E. Feinberg, Catalogue of an Exhibition held at the Detroit Public Library (Detroit: Aronsson Printing Co., 1955), p. 6.

5 By my count there are fifteen salmon sheets in Words, the greatest number running from sheet [261] to sheet [281]. See DBN III, 719-724.

6 Christian C. J. Bunsen, Outlines of the Philosophy of Universal History, Applied to Language and Religion, 2 vols. (London: Longmans, 1854). Bunsen's Outlines are the result of his collaboration with Max Muller, and they summarize the ethnolinguistic theories that grew out of the work of Wilhelm von Humboldt. For a recent account of Muller in which Bunsen receives some attention, see Linda Dowling, "Victorian Oxford and the Science of Language," PMLA, 97 (March 1982), 160-178.

7 Floyd Stovall, The Foreground of "Leaves of Grass" (Charlottesville: Univ. of Virginia Press, 1974), p. 164.

8 I have collated the Primer notes with White's scholarly edition in order to determine what type of paper was used for each manuscript page. The Williamsburgh tax forms make the following Primer pages: 89, 90, 91, 100-109.

9 The salmon sheets correspond to the following Primer pages: 2, 3, 92-99.

10 C. Carroll Hollis, "Walt Whitman and William Swinton: A Co-operative Friendship," American Literature, 30 (1959), 429-430.

11 Walt Whitman, New York Dissected, introduction and notes by Emory Holloway and Ralph Adimari (New York: Rufus Rockwell Wilson, Inc., 1936), p. 55. The entire article, with the editors' introduction, covers pp. 49-65.

12 Bowers, pp. xli-xliii.

13 The manuscript page is now in the Container 20 of the Feinberg Collection in the Library of Congress Manuscript Division. See John E. Bernbrock, S. J., "Walt Whitman and 'Anglo-Saxonism,"' Diss. North Carolina 1961, pp. 26-28, 36-38; cf. Bernbrock, "Whitman's Language Study: Work in Progress," Walt Whitman Review, 6 (1960), 69-72, and Michael R. Dressman, "Walt Whitman's Study of the English Language," Diss. North Carolina 1974, pp. 14-16.

14 This manuscript page is in Contaner 32 of the Feinberg Collection; the quoted title appears on the bibliographical card accompanying the page. The entire text of the manuscript, along with the bracketed note and Traubel's comment on the dating, appears in Horace Traubel, With Walt Whitman in Camden, II (New York: D. Appleton and Co., 1908), 246.

15 Michael R. Dressman, "Walt Whitman's Plans for the Perfect Dictionary," in Studies in the American Renaissance, 1979, ed. Joel Myerson (Boston: Twayne Publishers, 1979), pp. 457-473; see especially p. 467.

16 Walt Whitman's Leaves of Grass, The First (1855) Edition, ed. Malcolm Cowley (New York: Penguin Books, 1959), p. 47.

17 New York Dissected, p. 30. The entire article, with the editors' introduction, covers pp. 2740. 
18 New York Dissected, p. 59. The two language notebooks show Whitman's interest in previous lexicographers. Words contains detailed notes on the Introduction to Webster's Dictionary (DBN III, 713-718) and brief notes on the dictionaries of Bailey, Johnson, and Worcester (DBN III, 707). All of these notes appear, by the way, on Williamsburgh tax-form sheets. Whitman mentions Webster on a green sheet in the Primer (DBN III, 732).

19 Walt Whitman, The Complete Poems, ed. Francis Murphy (New York: Penguin Books, 1975), p. 767. In an earlier paragraph, Whitman alludes to "the lists of ready-made literature which America inherits by the mighty inheritance of the English language" (p. 764).

20 New York Dissected, p. 60. 